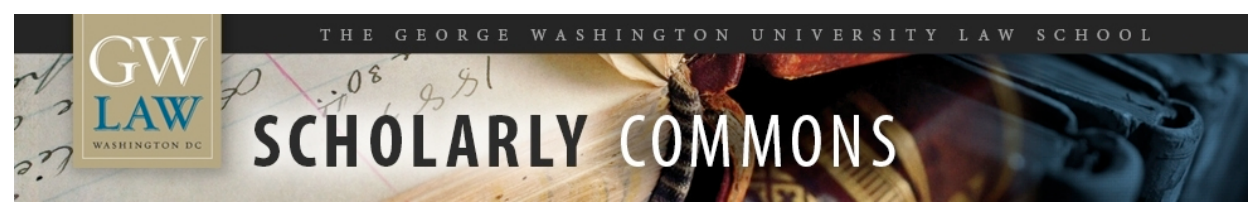

\title{
Placing Children in Context: Parents, Foster Care, and Poverty
}

Naomi R. Cahn

George Washington University Law School, ncahn@law.gwu.edu

Follow this and additional works at: https://scholarship.law.gwu.edu/faculty_publications

Part of the Law Commons

\section{Recommended Citation}

Naomi Cahn, Placing Children in Context: Parents, Foster Care, and Poverty, in WHAT IS RIGHT FOR CHILDREN 145 (Martha Albertson Fineman \& Karen Worthington eds., 2009).

This Article is brought to you for free and open access by the Faculty Scholarship at Scholarly Commons. It has been accepted for inclusion in GW Law Faculty Publications \& Other Works by an authorized administrator of Scholarly Commons. For more information, please contact spagel@law.gwu.edu. 


\title{
What is Right for Children?
}

The Competing Paradigms of Religion and Human Rights

\author{
Edited by
}

MARTHA ALBERTSON FINEMAN Emory University School of Law, USA KAREN WORTHINGTON

Emory University School of Law, USA 


\section{Chapter 8}

\section{Placing Children in Context: Parents, Foster Care, and Poverty}

Naomi Cahn

While the goals of the child abuse and neglect system have consistently focused on children's safety, its policies and practices have shifted historically on a continuum between child removal and family preservation. Many of the early child-saving organizations in the mid-nineteenth century sought to aid poor mothers and their children with the goal of keeping the family together, but other movements saw mothers as the enemy, as the people who beat and neglected their children, as those from whom their children needed to be protected.

Although the most recent debates over the federal approach to abuse and neglect have been similarly framed around child removal and family preservation, the implicit assumption in federal law has been that children's entitlement to safety requires that they be removed from their unsafe families of origin. The Adoption and Safe Families Act (ASFA) (1997) reiterated prior law in requiring states to make reasonable efforts to preserve and reunify existing families, but placed new emphasis on permanency planning and adoption. Rather than the previous focus on pursuing reunification before adoption, the ASFA allows for simultaneous pursuit of "reasonable efforts to place a child for adoption or with a legal guardian [and] reasonable efforts [to reunify]" $(\S 671(\mathrm{a})(15)(\mathrm{F}))$. Moreover, if reunification efforts would conflict with a permanency plan, then the plan takes priority. The legislation also provides incentive payments to states to increase the number of children adopted out of foster care. The ASFA reflected a major shift in federal policy toward abused and neglected children and is a dramatic change away from efforts to preserve families toward efforts to create new families for the children. Particularly for poor and African American children who are disproportionately subjected to the foster care system, the efforts towards permanency planning result in unfair and untimely disruptions of their relationships with their parents. According to the US Census Bureau, 13 million children in the United States, or 17.8 percent of American children, lived at or below the federal poverty line in 2004 (US Census Bureau, 2005). Additionally, more than one-half of the children in foster care in 1999 qualified for federally assisted foster care, which is tied to eligibility for welfare benefits (Barbell and Freundlich, 2001). Unstable sources of parental income are the major determinant of children's removal from their parent's custody, while the severity of child maltreatment is not as strong an indicator (Barbell and Freundlich, 2001). 
Children's rights to grow up in a safe environment should continue, of course, to be central to any reforms in the abuse and neglect system. But those rights must be placed in the context of, first, children's familial interests of maintaining contact with their parents, siblings, and other relatives, and second, the policies and practices of the existing child welfare system. Removing children from their families of origin may disrupt the otherwise strong emotional bonds between family members and have a particularly severe impact on the child. While the framework for theoretical discussion of the abuse and neglect system often focuses on tensions between parents' familial rights and children's protective rights, between family preservation and child removal, this framework obscures the overlapping interests of parents and children.

The ASFA represents a shift towards child rescue and remains an overreaction to a perceived bias towards family preservation. Displacing the continuum of preservation and protection by focusing on children in context may result in more humane child protection practices. Indeed, the historical development of federal support for foster care over the past century shows shifting priorities between in-home and out-of-home care, even though prevention is more economically efficient than removal. The tensions between supporting a child inside her family and outside her family are enduring. This chapter advocates a returned focus on children as members of an existing family within a larger community as the means for grounding the child welfare system. It is thus paradoxical to pursue reunification with that family and also to pursue adoption. Each disposition may be appropriate for any particular child at a specific time, but pursuing both charts is an inconsistent course. Emphasizing the child in context should result in allocating more resources for the child's successful return (or even better yet, for preventing removal altogether) and for allocating more resources to support families.

This chapter begins with an overview of federal involvement in foster care, starting with the 1909 White House Conference on Dependent Care, to show the historical relationship between aid to children and in-home care. Part two discusses the relationship between poverty and the abuse and neglect system. Part three provides a fuller examination of the implications of the 1997 changes in abuse and neglect policy for poor children. Part four concludes by suggesting alternative approaches to the current abuse and neglect system that will keep children safe in their families, exploring the many means for dissolving the perceived dichotomy: protecting children and preserving families.

\section{Federal Involvement in Foster Care}

On January 25, 1909, President Theodore Roosevelt convened the White House Conference on the Care of Dependent Children, which had a goal of formulating policies to care for poor neglected children who were not juvenile delinquents (Crenson, 1998). At the end of the conference, the participants, including Jane Addams, Booker T. Washington, and Theodore Dreiser, proposed to make payments 
to poor parents so their children could stay at home rather than be removed to an orphanage. Conference members did not specify the source of payments, although they advocated private relief (Skocpol, 1992). Two years after the conference, Illinois and Missouri adopted mothers' pension laws. Many states followed soon thereafter. These pensions were paid to widows who qualified on various moral grounds for financial relief (Skocpol, 1992), and a 1931 survey found that more than 95 percent of the recipients were white (Onwuachi-Willig, 2005; Cahn, 1997). The mothers' pension laws certainly received an impetus from the White House Conference, but they built on Progressive Era beliefs that idealized motherhood and the family. As one of the Progressive Era women's magazines explained, mothers' pensions provided compensation to women just as wages provided compensation to men: "[A man] is paid for his work; she for hers. And she should be paid by those for whom she does it - all the citizens of the state" (Crenson, 1998, p. 264).

Although the pensions were limited in their coverage, the mothers' pension movement thus represented an effort not just to alleviate poverty but to keep children out of orphanages and foster care. Matthew Crenson (1998) notes that, as early as the 1860 s, orphanages gave money to families to enable care for children so that the orphanage would not become overcrowded. It should be duly noted that the development of foster families occurred during the latter part of the nineteenth century as well. Other early twentieth-century governmental efforts were similarly designed to promote maternal care of children. Beginning with these early mothers' pension laws, there has been a strong link between aid to dependent children and the assumption that this aid would allow children to be cared for at home, the most suitable environment for them. Similarly, as traced in a 50-year history of the efforts of the Federal Children's Bureau, child welfare agencies shifted their focus from outside placement to maintaining children at home.

In providing federal aid to dependent children, the government was clearly attempting to provide support so that children could stay within their families when those families were appropriate recipients of aid. States developed their own standards as to which families qualified for aid. Based on the widespread variation in the standards for qualification, including attempts to preclude nonmarital children from receiving aid, in January of 1961, the Secretary of Health, Education, and Welfare prohibited states from terminating aid to children if their homes had been found unsuitable (Ross and Cahn, 2000).

So strong was the policy of providing support only for children who lived at home that until 1961 a child was ineligible for Aid to Dependent Children (ADC) unless she was living with her parent or a close relative. A child who had been removed for abuse and neglect, then, was no longer eligible for aid under the federal program. In 1961 , Congress enacted legislation expanding ADC and changing its name to Aid to Families with Dependent Children (AFDC). The legislation was designed to allow children who were needy due to parental unemployment to receive aid. As part of this massive revision to aid for needy children, Senator Robert S. Kerr of Oklahoma proposed to the Senate Finance Committee that children removed from their homes for abuse and neglect pursuant to a court order be eligible for continued federal aid 
(Cahn, 1999). Senator Kerr observed that he had offered this amendment because some state courts might feel a psychological barrier to removing a child from an abusive or neglectful home because that child would lose federal aid and become dependent on the state or locality instead. The Finance Committee echoed his concern, explaining that it was worried that the unavailability of continued federal aid had interfered with courts acting in the child's best interests; prior to the 1961 amendment, the only federal money available for foster care came from Title V of the Social Security Act.

There was relatively little debate over the foster care amendment. The primary controversies on the Senate floor concerned the availability of continued federal aid to a child placed in a foster home where she was receiving religious instruction, as well as the potential federal interference with state foster care programs. Senator Kerr explained that the federal government was not intending to interfere in any way with state laws and policies concerning foster care, nor with intrafamilial relations. Instead, he wanted to ensure that courts felt free to act in the child's best interests without feeling financial constraints. Moreover, the amendment contemplated only private, state-licensed foster care homes, not institutional care, and thus religious instruction would not be an issue (Cahn, 1999).

Since 1961, the federal government has become increasingly involved with foster care and has consistently attempted to influence state foster care programs. As the population of children in foster care increased dramatically during the 1970s, Congress held hearings on how to manage the crisis. In 1980, Congress removed the federal foster care system from Title IV-A of the Social Security Act and established a separate program under Title IV-E through the Adoption Assistance and Child Welfare Act (AACWA). The AACWA attempted to federalize state foster care programs by establishing comprehensive standards, and it emphasized the importance of providing reasonable efforts both to prevent a child from being removed from her family and to return her to her family. It also regularized federal reimbursements for state-approved foster care. Under the AACWA, states were required to submit a plan to the US Department of Health and Human Services (HHS), which provided that in each case, "reasonable efforts will be made ... (i) prior to the placement of a child in foster care, to prevent or eliminate the need for removal of the child from his home, and (ii) to make it possible for the child to return to his home" ( $\$ 671)$. Moreover, in order to remove a child from her home, states were required to show that the removal occurred because staying in the home would be "contrary to the welfare of such child" and that reasonable efforts to keep the child at home had been made ( $\$ 672$ ).

In the hearings that culminated in the 1997 ASFA legislation, witnesses repeatedly emphasized the problems resulting from provisions in the 1980 law requiring reasonable efforts be made to reunify troubled families. Witnesses to the hearings before the House Ways and Means Committee recounted the physical, emotional, and sexual abuse visited upon children as a result of their return to the custody of biological parents suffering from substance abuse, mental illness, or other conflicts preventing their full assumption of responsibility for the care 
of their children (Cahn, 1999). Foster parents and adoptive parents described their efforts to extricate children from troubled homes, only to face recalcitrant judges, social workers, and other actors in the foster care system who enforced compliance with family preservation and reunification policies devised pursuant to the statutory mandate to make reasonable efforts to reunify families.

Moreover, the problems stemming from family preservation and reunification policies were not limited to the abuse inflicted upon children when their biological families resumed custody. Heads of government agencies, attorneys who represented children or parents in the foster care system, and prospective adoptive parents outlined the destabilizing effect of placing children from troubled families in multiple foster homes, while government or non-profit agencies administered services to the parents to successfully reunite them with their children. To those individuals who testified at the hearings, the reasonable efforts requirement in the 1980 legislation had been interpreted by many jurisdictions as a requirement that agencies undertake all possible efforts to reunify or preserve the family unit, without regard to the welfare of the children (Cahn, 1999).

The ASFA (1997) seeks to prevent children from spending excess time in foster care and to promote adoption. To accomplish the first goal of preventing foster care drift, as well as the second goal of freeing children for adoption, the ASFA requires, among other things, that a state seek to terminate parental rights for children who have been in foster care for 15 out of the previous 22 months. It also requires that a permanency hearing be held within 12 months of a child's entry into foster care, in contrast to the AACWA, which required simply that a dispositional hearing be held within 18 months. The permanency plan required by the ASFA must include a schedule for: (1) returning the child to her parent, if that is an option; (2) placing the child for adoption and terminating her parents' rights; or (3) referring the child for permanent placement. As an additional method of promoting adoption, the legislation authorizes financial incentives of up to $\$ 6,000$ per child adopted. Finally, the Act clarifies that children's safety concerns are the paramount consideration in any family preservation, foster care, or adoption effort.

\section{Problems with the Return to Removal}

Although each end of the policy continuum-removal and family preservationhas overlapping goals of keeping children safe, the removal focus risks ignoring the socio-economic (as well as the familial and community) context of most children involved with the protective services system.

\section{Poverty and the Abuse and Neglect System: The Relationship Between Poverty and Child Protective Services}

The tensions between the two different meanings of the child welfare system-the welfare system that provides aid to children and the welfare system that protects 
children from abuse and neglect-are longstanding. Historically, there has been a strong link between race, child abuse and neglect, and poverty. Poor and African American families are disproportionately more likely to be charged with child neglect; black children are twice as likely to be removed from their families as are white children (Appell, 2004a; Roberts, 2003). In 2001, blacks constituted approximately 12 percent of the population, but 38 percent of children in foster care were black; however, 75 percent of the population was white but only 37 percent of the children in foster care were white, and Hispanics were 12.5 percent of the population but represented 17 percent of the children in foster care (Brown, 2006). As discussed below, African American children are involved with the system longer than white children (Foster Care, 2003). Furthermore, African American children are more likely to be placed in residential or group care than in foster care and are less likely to be reunified with their families (Annie E. Casey Foundation, 2004).

Studies show that children in families with incomes less than $\$ 15,000$ per year are 45 times more likely to be victims of substantiated neglect than children in families with incomes greater than $\$ 30,000$ per year (Chipungu and Bent-Goodley, 2004). The reasons for this variation are unclear, although it is certainly not poverty alone that causes abuse. Instead, it appears that poverty interacts with a series of other factors. The association between poverty and neglect is particularly strong. Children may be removed for poverty alone. One Illinois study found that almost 10 percent of children were removed because of "environmental neglect," which is broadly defined as a lack of adequate food, shelter, or clothing (Shook, 1998), rather than any deliberate actions on the part of the parent, and another 12 percent were removed for lack of supervision. These are resource problems, not abusive or neglectful parents. If there is adequate funding for life's necessities, poverty alone will not cause neglect. Similarly, if parents received adequate support to care for their child, for example, to pay for day care or after-school programs, then this will ameliorate the lack of supervision problem.

A study of child abuse in Denver found that children in single-headed, African American households were more likely to be reported for abuse than were white children living in two-parent households who had been abused (Jenny, Hymel, Ritzen, Reinert, and Hay, 1999). Physicians missed child abuse in white children at a rate of about 40 percent, and for black children, 20 percent (Jenny et al., 1999 , p. 623). While there were comparable rates for single-headed versus twoparent families, I think these studies show the abuse and neglect system is not administered even-handedly. They also show there is a high correlation between poor families and that system. In addition, over one-third of children in New York City's foster care system receive public welfare.

\section{Welfare Law and the Abuse System}

Furthermore, the disappearance of Aid to Families with Dependent Children and its replacement by the Temporary Assistance to Needy Families (TANF) program 
created more possibilities for poor people to interact with child protective services. New opportunities for involvement with child protective services result from several sources (Courtney, 2005). First, the welfare-to-work program requirements result in a series of difficulties for parents. Early speculation indicated the program might lead to parents leaving their children unattended due to the lack of good child care (Matthews, 1999). When parents are ineligible for public welfare and are unable to work, they are also unable to provide food and shelter for their children, which leads to the potential encounter with child protective services. Once a child is removed, the requirements needed for a reunification plan in conjunction with a work plan may make it difficult for a parent to comply with both. These dualsystem families may find it difficult to attend child protective court hearings or to visit their children in foster care. Although data are somewhat ambiguous on these issues, early analyses showed that TANF appears to have resulted in a change in childrens' entry into the neglect system, with some states showing an increase in abandoned children or children receiving inadequate supervision from working parents (Congressional Research Service (CRS), 2002). However, a large study finds that higher benefit levels were associated with lower levels of neglect and fewer children in foster care (CRS, 2002).

Moreover, welfare recipients who work appear to be at higher risk of having their children placed in foster care, and the reunification process is longer, perhaps because of the multiple demands of the differing public programs (Green, 2002; Nam, Meezan, and Danziger, 2006). Second, drug testing requirements for TANF applicants may prevent families with substance abuse problems from applying for benefits, thus resulting in greater poverty and more contact with the child protection system. Child abuse and neglect studies indicate between one-third and two-thirds of all substantiated reports involve some form of parental substance abuse. Third, with a decrease in the number of families on public assistance there may be more voluntary placements in foster care as parents try to help their children by placing them elsewhere. As this chapter shows, the abuse and neglect system is integrally tied in with child poverty, and changes in each system affect the other.

\section{Problems with the Adoption Emphasis}

The ASFA isolates a significant moment in a child's life - the incident of abuse or neglect that led to removal-from the child's lifetime relationship with her parents, her extended family, and her community. In order to facilitate adoptions, the ASFA provides for speedier termination of parental rights through a variety of mechanisms. These provisions are eloquent on paper, but ill-advised in practice.

First, the ASFA assumes that a certain amount of time in foster care means that the parents are, and will continue to be, unable to care for their children. Once a child has spent 15 months out of the prior 22 months in foster care, the state is required (with a few exceptions) to initiate proceedings for termination of parental rights. Such an assumption is unwarranted under many circumstances (Cahn, 1999; Ross, 2004b). The length of time for permanency planning, especially because 
it is not based on any substantive ground, ignores the relationship between the child and her parents. It overlooks the actual reasons a child may be in foster care and is unmoored from any "reasonable efforts" to return the child to her family. States could use the length-of-time ground even when parents are responding to services and the child would like to return home. As Marylee Allen from the Children's Defense Fund explained at hearings on the ASFA, "[c]onsider a situation, for example, where a parent has successfully completed substance abuse treatment, has begun weekend visits with the children, had one child returned and will have the other two children returned within the next two months" (H.R. 867: The Adoption Promotion Act of 1997, pp. 33-4). Instead of helping children, terminating parental rights based on length-of-time could be affirmatively harmful to children and the stability of their relationships.

Second, in implementing the ASFA, states have considered and adopted legislation that is particularly punitive to families of origin. For example, in Arkansas the welfare agency can only continue to pursue reunification when the parent is making "significant, measurable progress" under the goals of the case plan (Arkansas Code Annotation 2006, $\S 9-27-338(c)(5)$ ). The statute places the burden of proving a "genuine, sustainable investment" in completing the provisions of the case plan and complying with court orders on the parent; if she fails to meet her burden the agency need not pursue reunification. As one Arkansas court explained, "[w] agree that the plain language of [the statute] does express an order of preference for permanency goals, and that adoption is the preferred disposition" (Arkansas Department of Human Services v. Mays, 2004, p. 6). Louisiana legislation requires that the case plan contain documentation of the "compelling reasons for determining that filing a petition for termination of parental rights would not be in the best interest of the child, when appropriate" (Louisiana Children's Code, 2005, Article 675, B.5). In Nevada, a parent's failure to comply substantially with the terms of the reunification plan within six months of the child's placement is evidence that could lead to termination of parental rights (Nevada Revised Statutes, 2005, § 128.109(1)(b)). Similarly, in Arizona parental rights are terminated if the child has been in an out-of-home placement for nine months and the parent has substantially neglected or willfully refused to remedy the circumstances that caused the out-of-home placement (Arizona Revised Statutes Annotation $\S 8-533,2005$ ). Parental rights may also be terminated when the parent has participated in the reunification services, but has been unable to remedy the circumstances that caused the out-of-home placement after 15 months.

In Delaware parental rights can be terminated if the parent fails to "visit regularly with the minor" for a period of six consecutive months (Delaware Code Annotation, 2005, § 1103). In Alaska reasonable efforts to reunify the family are not required when the parent has failed during the preceding 12 months to participate in family support services (Alaska Statutes $\S 47.10 .086,2005$ ). As of September $30,2000,131,000$ children in foster care were waiting to be adopted; the parental rights of 75,000 of these children had been terminated and they had been waiting an average of almost two years for adoption (Allen and Bissell, 2004). 
Third, the ASFA seems to blame the length of time children stay in foster care on their biological parents' inability to pull their lives together, independent of any hoped-for intervention by social workers seeking to offer the requisite reasonable efforts. This intervention is highly improbable in light of the severe funding shortages and urban child welfare systems' high caseloads. Families are simply not receiving the necessary services; they are not refusing to comply with the offered services. Even where child maltreatment has been substantiated, approximately 40 to 60 percent of these cases receive no additional services (Cahn, 1999, p. 1203). Fewer than 10 percent of child welfare agencies are able to find substance abuse treatment programs for most of their clients within 30 days (Cahn, 1999, p. 1203). In one study two-thirds of states reported the lack of appropriate services for parents once a child entered foster care. In particular, programs treating substance abuse posed a major obstacle to permanency planning (Allen and Bissell, 2004). In addition to the critical shortage, the programs that do exist are not designed for women who want to continue to parent, so they may not be able to provide sufficient support (Eichner, 2005). Given that the children's case plans inevitably require treatment for their parents, the unavailability of programs means that children will remain in foster care and, thus, delay or terminate reunification. Further there is no requirement for providing additional services to parents and children to facilitate reunification, yet at the time Congress was considering the ASFA, there were lawsuits in almost half the states because of inadequate child welfare systems (Ross, 2004b). There are a limited amount of funds available for providing inhome services-versus the much larger amount available for maintaining children in foster care-making it difficult for states to place any priority on these issues (Scarcella, Bess, Zielewski, Warner, and Geen, 2004).

In addition, judges have enormous discretion in deciding whether the state has met the reasonable efforts requirement, and they rely on the testimony of underfunded child welfare workers. In many decisions, it is the child welfare agency's failure to offer adequate services, rather than the parent's failure to comply with reunification efforts, that explains the lack of reasonable efforts (Kim, 1999).

\section{Families' Identity, Children's Interests}

In arguing that the law should respect the integrity of the family unit, I want to place this concept in the context of children's interests. Of course, in addressing how best to respect children there are many different frameworks and many disagreements on what should be the focus. Parents can only be defined in relationship to children. Respecting families does not mean jeopardizing children. It is not a choice in which we respect either parents or children; their rights generally do not conflict. Instead of reifying a dichotomy between the interests of parents and the interests of children, we should recognize that, in most cases, they overlap significantly. Martha Minow (1996) reminds us of the importance of not basing politics solely 
on one's identity. General cultural assumptions that children are cared for by their parents serves to respect children's interests. Respecting "rights for children" requires "concern about the importance of connection, care-taking, and social relationships," as well as acknowledging the "critical role of relationships with adults" (Minow, 1986, pp. 3, 18).

\section{Parents and Children's Interests}

Even when their interests diverge, respecting children's interests and safety does not mean overlooking adults' interests. Nor should recognizing adults' interests mean trivializing children's interests. While it is critical to respect children's rights and relationships, make decisions that are in their best interest, and listen to them, I believe that parents' rights can also be respected without classifying children as "property" or ignoring the children's actual interests. Whether one recognizes the interests of parents or the interests of children, either view recognizes the needs of both the individual and community, of both autonomy and family.

Parents develop complex emotional and psychological bonds with their children that should be respected by the law (Fineman, 1999). Even when children do not live with them, parents can develop significant relationships with their children that benefit both the parent and the child. There is a bond that develops out of parents' connection to their children which, in turn, becomes part of how parents define themselves. This bond can develop in many different ways, and it does not automatically develop because of a biological connection. While children undoubtedly need stability and continuity to thrive, the recognition of a connection between children and their biological parents is not inherently destructive.

Respecting this bond is respecting the emotional connection. It is very different from giving parents rights because they own their child, as was true when fathers "owned" their children's labor. While I agree that "inchoate possessory rights" (Woodhouse, 1995, p. 2520) do not entitle a parent to continue to abuse her child, I do not think that notions of children as property are what is underlying the removal of abused and neglected children. Instead, I believe that children are too often removed without an adequate examination of how to support their biological parents. Such examination is necessary so that children's lives are minimally disrupted.

There can be no universal presumption that parents will always want what is best for their children, although this remains a good working hypothesis (Fineman, 1999). An abusive mother who wants custody of her daughter creates a very dangerous situation. In the short term contact would be harmful. In the long term, however (and depending on the nature of the abuse, of course), the mother's wishes could be partially accommodated through carefully structured visitation protecting the daughter. The mother has some affective interest that differs from a property right in maintaining contact with her child and the child often has some affective interest in maintaining contact with her mother. If the mother, nonetheless, attempts to continue the abuse, then she clearly should not be allowed continued access to her children. 
Divorce is another context where parents are separated from their children. We accord the non-custodial parent visitation rights, even at the potential expense of the child's best interests. I believe that we do this in recognition of the non-custodial parent's relationship to his child. Even though some of our most influential child psychologists argue to the contrary, courts believe that two parents are best for every child. I think we hold such a deep belief, in part, because we want to find some way of granting the non-custodial parent some rights in her child. Furthermore, the child's best interests are not unmoored from the identity of her parents. State statutes require that the parents' wishes be considered in child custody litigation. The parents' wishes are not determinative, nor should they be. But a custody standard that did not consider how the parents feel about their child would be a travesty.

Assuming the parents want to remain connected to their children because children "belong" to them like "property" demeans the conception of parenthood. So does removing a child from a familial situation because of neglect resulting from poverty. The dichotomy between "child-centered" law, focusing solely on children's best interests without deference to their parents, and "childrenas-property" law, focusing only on those to whom the children belong, is false. Advocates of a child-centered focus bring critical attention to issues concerning children by forcing us to listen to children and attend to their needs. While it is somewhat harder to defend the children-as-property perspective, I think it suggests that parents have rights that must be respected. These positions exist on a continuum and child welfare policy should respect the interdependent nature of the rights of children and parents. Children generally need their parents and their parents depend on support from others.

Moreover, a sole focus on parent or child, or even a focus solely on the parentchild relationship, overlooks the child as a member of a family and a community. A family includes not just parent(s) and child, but also siblings, grandparents, and other relatives. In determining removal, foster care placement, reunification, and adoption, the child's interests must include a consideration of her relationships with these other people. Looking at children in this context considers their relationships to parents, siblings, and other relatives. While this has led to increased use of kinship care, it should also result in fewer removals and more emphasis on reunification.

\section{Poor Children, Poor Parents}

The foster care system is primarily populated with poor children. The goal of permanence, of getting children out of the limbo of foster care, has enormous symbolic value. Adoption symbolizes a complete change in a child's family structure. Her biological parents' rights are terminated and she receives a new birth certificate reflecting her adoptive family as her birth family. All ties with her family of origin are severed and she is able to begin a new life. Outside of the child welfare system, constitutional and statutory law generally support the proposition that parents are the 
most appropriate custodians for their children. Our protection of the family through notions such as family privacy and integrity has, however, depended on the family's class (Fineman, 1999). Wealthier families have always received more protection for their familial-based decision making, as the very history of public welfare to children shows. The history of aid to poor women is replete with attempts to control their lives by conditioning public welfare on their compliance with morality requirements that involve state supervision of their lives.

There are arguments for protecting children regardless of the parents' situations. For example, Elizabeth Bartholet (2000) argues that it is important to move abused, perhaps even neglected, children into other homes where they will receive the nurturing they need, rather than leaving them with their biological parents. In contrast, Dorothy Roberts (2002) argues for more intensive resources directed at keeping children in their families. She advocates better public support for children and community-based and guided interventions.

This debate echoes other issues involving parents and children and the appropriate structure for recognizing children's rights. A line of Supreme Court cases guarantee parents a constitutional right to raise a child in the manner they choose. In Meyer v. Nebraska (1923) the Court held that the right of liberty "denotes not merely freedom from bodily restraint but also the right of the individual to contract, to engage in any of the common occupations of life ... to marry, establish a home and bring up children" (Meyer, 1923, p. 399). In Pierce v. Society of Sisters (1925), the right is phrased as harking back to Meyer:

The fundamental theory of liberty upon which all governments in this Union repose excludes any general power of the State to standardize its children ... The child is not the mere creature of the State; those who nurture him and direct his destiny have the right, coupled with the high duty, to recognize and prepare him for additional obligations. (Pierce, 1925, p. 535)

Similarly, in Farrington v. Tokushige (1927) the Court held that restrictions on teaching foreign languages in Hawaii deprived Japanese parents of the right to direct their children's education. In addition, in Wisconsin v. Yoder (1972) the Court observed that parental control over their children's religious and educational upbringing has "a high place in our society," and the state's interest in education must be balanced against "the traditional interest of parents with respect to the religious upbringing of their children" (Yoder, 1972, pp. 213-14). In Troxel $v$. Granville (2000), the Supreme Court reiterated that parents have a basic right to raise their children and that the decisions of fit parents should receive great deference. Each of these decisions occurred within the context of a nuclear or natural family. However, when an unmarried father challenged an intact nuclear family, he lost (Michael H. v. Gerald D., 1989).

Parents' basic rights become attenuated as soon as the parent or parents' fitness comes into question (tenBroek, 1964; Wyman v. James, 1971); indeed, this is the premise of child abuse and neglect statutes. While courts pay deference to the notion 
of parental control, the state can remove children from their parents for abuse and neglect, require some form of schooling, and establish a minimum work age for children (Ross, 1996). Moreover, the Supreme Court has recognized that children have some basic minimal rights as well that can be asserted on their own behalf.

Scholars have debated the issues involving children's rights when they conflict with parental rights. The Court has largely reinforced the notion that the traditional family unit provides adequate constitutional protection for children. Particularly in the substantive due process context, the Court has tended to equate children's interests with those of their parents and to protect children derivatively, through such doctrines as parental autonomy and familial privacy. Similarly, when it comes to children's rights to receive adequate services to prevent abuse and neglect, the Court has generally reinforced the state's decision-making process rather than children's rights (DeShaney v. Winnebago County Department of Social Services, 1989; Suter v. Artist M., 1992).

Parents' basic rights, however, remain based on the form of the family and also on class. As Jacobus tenBroek (1964) originally pointed out more than 40 years ago:

We have two systems of family law ... One is public, the other private. One deals with expenditure and conservation of public funds and is heavily political and measurably penal. The other deals with the distribution of family funds, focuses on the rights and responsibilities of family members, and is civil, nonpolitical, and less penal. One is for underprivileged and deprived families; the other for the more comfortable and fortunate. (tenBroek, 1964, pp. 257-8)

This two-tiered model pervades every aspect of family law as a result of, first, the different laws that apply to rich and poor; second, the differential administration of any applicable law; and third, the different patterns of usage of existing laws, which seem affected by class. In the foster care context this dual system is transparently clear; federal foster care funds are not even available for children who are not eligible for public aid. Abuse within wealthier families is simply not subjected to the same level of scrutiny. The interdependence of class and parental rights is illustrated by Wyman, a 1971 Supreme Court decision. Ms Wyman, a public welfare recipient, refused to allow her caseworker to visit her home. She told her caseworker that she would provide any information that was relevant to her continued receipt of welfare, but that the caseworker could not make a home visit. At the time New York state law required home visits to public welfare recipients once every three months; the various purposes were to verify information concerning eligibility for welfare, provide professional counseling, and prevent welfare fraud. Additionally, New York law specified that a child would only be eligible for aid "if his home situation is one in which his physical, mental and moral well-being will be safeguarded and his religious faith preserved and protected" (Wyman, 1971, p. 312). Although a three-judge district court struck down the home visit requirement, the Supreme Court reversed that decision. The opinion focused on distinguishing a true Fourth Amendment search--the visitation at issue was not forced, compelled, 
or backed up by criminal penalties (Wyman, 1971). There was, not surprisingly, a strong dissent by Justices Marshall and Brennan, explicitly confronting the class implications of the case. They explained:

[I]t is argued that the home visit is justified to protect dependent children from "abuse" and "exploitation." These are heinous crimes, but they are not confined to indigent households. Would the majority sanction, in the absence of probable cause, compulsory visits to all American homes for the purpose of discovering child abuse? Or is this Court prepared to hold as a matter of constitutional law that a mother, merely because she is poor, is substantially more likely to injure or exploit her children? (Wyman, 1971, pp. 341-2)

However, the dissenters also noted that the home visit was justified to ensure adequate information to confirm the family's eligibility for public welfare. Ironically, the federal regulations specified that the parent should serve as the primary source of that information. The intrusiveness of the home visit and the alleged necessity of independent verification indicate that a poor mother is not to be trusted to comply with public welfare requirements concerning money or her child.

Given the number of children who are removed for poverty alone, a sole emphasis on best interest of the child also leads to class and race bias. Instead, children must be viewed in their familial contexts - their relationships to their siblings, parents, relatives, and community-and must be supported in these contexts. Removing a child from her family disrupts all of these relationships. While removal can certainly be justified where there is severe abuse or where the child will not be safe, for most families there are means short of long-term removal that will provide benefits to the child.

This is particularly relevant for African American children, whose foster care placement rate is twice as high as that of white children. An overwhelming majority of white children ( 72 percent) in the abuse and neglect system receive in-home services, while only 44 percent of African American children receive in-home services (Cahn, 1999). The dimensions of this disparity do not reflect differences in the population of children referred to the child welfare system. Indeed, the Department of Health and Human Services concluded in 1997 that "even when families have the same characteristics and lack of problems, African American children, and Hispanic children to a lesser extent, are more likely than white children to be placed in foster care" (Cahn, 1999, p. 1212). In addition, African American children spend more time in foster care than do white children (Roberts, 2002). The disproportionate representation of poor and A frican American children in the abuse and neglect system shows that something other than the need for more permanency is wrong with the system.

Thus, one response to claims of an excessive focus on parents' rights to keep their children is to point out the race and class-based nature of the family integrity doctrine. In response to the children's rights perspective, Dorothy Roberts (2002) provides another view; she argues that it is in fact a violation of children's rights 
to remove them from their families of origin. For example, federal law favoring adoption "does not further the interests of most children in foster care" (Roberts, 2002 , p. 257) who would be better served by remaining with their parents. Instead, she identifies children's rights as part of a larger struggle against oppression, so that all children will be valued. She does not deny that child abuse and neglect are bad for children; rather her solutions are not to remove children from their parents but to provide support so that parents can raise their own children. Instead of viewing children as separate entities from their families and communities, they should be placed in context.

The premise of both the foster care system and TANF is to provide support for the child in whatever familial unit she is currently living, rather than to provide support to the familial unit (Ross and Cahn, 2000). The willingness to focus solely on the individual child reflects much broader social, legal, and philosophical notions about the child as a future deserving citizen of the state, who is valuable regardless of the suitability or desirability of her parents (Prince v. Massachusetts, 1944; Zelizer, 1985). Instead, recognizing children's developmental needs requires recognizing their relationships with others.

\section{Suggestions for More Humane Implementation}

Placing children in a relational context requires careful thinking about alternatives to traditional foster care and adoption, acknowledging both the importance of family preservation and removing the child when the family is unsafe. One comparatively recent innovation is an increase in use of kinship care, allowing relatives rather than strangers to care for children after removal. While this allows a child to maintain connections with her family, it attempts to ensure the safety of her familial placement. Others suggest changing the standard for intervention such that child protection authorities could not remove children unless placement in foster care would be more effective than remaining in the home situation (Cahn, 1999). Such a proposal grapples with the foster care system's inadequacies as well as the benefits of maintaining a child's family of origin. An additional protection, which would be particularly helpful for poor families, would mandate courtappointed counsel for all parents involved with the abuse and neglect system, from the initial suspicion of neglect through all subsequent proceedings. There are many additional mechanisms that keep children safe without terminating their familial ties (Eichner, 2005). There are many kinds of interventions before a child is removed that may be effective in preventing her removal. Examples include parenting classes, home visiting, helping parents find housing and jobs, coordinating public welfare services and domestic violence interventions, and providing more intensive substance abuse programs. Even after substantiation of abuse or neglect, studies have found that the majority of children in out-of-home care could safely live at home (Guggenheim, 2000). 
Several states have implemented screening programs in which the child welfare agency investigates only the most severe cases of alleged abuse and neglect, while other cases are referred for family assessment and support. A broader vision of child welfare services would involve support for children's existing needy families and would place less focus on punishing those families (Guggenheim, 2000).

One of the many shortcomings of the child abuse prevention system is a failure to look at other family members and the larger socio-economic contexts in which children grow. Dorothy Roberts (2005) advocates a community approach to handling child abuse and neglect, with services generally available to all members of the community. Additional solutions expand upon this contextual approach. A widely noted decision concerning New York's child protective services system found that the system was disproportionately removing children from battered women. The women were blamed for their victimization and their children were placed in foster care (Nicholson v. Williams, 2002; Ross, 2004b). The higher rate of incarceration among African Americans (Butler, 1997) means that parenting issues are particularly difficult; changing how child protective services deal with incarcerated parents would also help racial disparities in the child welfare system (Cahn, 2000). While more than 64 percent of incarcerated mothers had lived with their children prior to incarceration, fewer than half of all mothers in prison had ever had personal visits with their children (Mumola, 2000). When men go to prison, their children are most likely to live with their mother; when women go to prison, the children are most likely to live with other relatives or to be placed in foster care. Women are decontextualized and treated as prisoners without the recognition that imprisonment does not necessarily "mean that a parent cannot continue a loving, committed relationship with his or her child" (Schneider, 2002, p. 54).

There are a series of different strategies that states, localities, and non-profits can undertake both before a child is removed and afterwards to encourage reunification. These strategies do not necessarily involve additional state and federal expenditure on abused or neglected children. Instead, they involve reallocating existing resources. Given the disparities between the amounts of money expended when a child remains in her home as opposed to being placed in foster care, maintaining in-home placements could be supported without additional money. Spending the money well before a child is removed, such as when the risk is initially identified, could prevent escalation of the abuse or neglect as well as a foster care placement.

It is critical to eliminate race-based disparities throughout the system in considering changes to abuse and neglect services. That is an extremely difficult premise to implement within our contemporary culture. Using more communitybased interventions is one effective method of distilling the racism pervading the abuse and neglect system. In addition, child welfare agencies need training and monitoring on these issues. States are increasingly implementing "alternative responses" which focus on response to the family's needs and prevent further maltreatment, rather than documenting abuse or neglect and imposing 
interventions (Shusterman, Hollinshead, Fluke, and Yuan, 2005). Involving the family in planning various interventions commits family members to change (Huntington, 2006).

\section{Pre-Removal}

Child welfare systems generally involve three functions: protective services, foster care and adoption services, and family support (or preservation) services (McCroskey, 2001). The federal government allocates approximately 10 percent of its child protective services budget to family preservation and reunification. The remainder is spent on foster care and adoption promotion (US Department of Health and Human Services, 2005b). Although both the AACWA and ASFA mandate intensive pre-placement services, the structure of federal funding for child welfare remains grossly skewed in favor of subsidizing foster care rather than promoting preventive programs. Family preservation may involve specific, crisis-oriented services, or as many of us advocate, an approach that focuses on the child within her familial context. Family preservation can encompass a variety of services, such as improving parenting skills and preventing foster care placement (McCroskey, 2001). Given the relationship between poverty and neglect, more public welfare funds and better support for poor working parents might obviate the need for any involvement with the abuse and neglect system.

\section{The Child Protection Agency}

Child welfare agencies have a variety of tasks, despite frequent understaffing and low funding. In 1996, immediately prior to the ASFA, child welfare agencies in 21 states were subject to court supervision based on their failures with respect to their child abuse and neglect systems. For example, the foster care system in the District of Columbia was placed in court-ordered receivership in 1995, and the New York City foster care system has been under legal attack for its failure to protect children.

Professor Leroy Pelton has suggested restructuring the child protective services agency to focus on children's issues rather than on investigative and lawenforcement processes (Pear, 1996). Such a reconstruction might make clients more comfortable in seeking and accepting preservation services if they know they are getting help rather than subjecting themselves to a high risk of child removal. Several states have implemented screening programs in which the child welfare agency investigates only the most severe cases of alleged abuse and neglect, while other cases are referred for family assessment and support (Waldfogel, 1998).

\section{Emphasizing Community Involvement}

States are also experimenting with greater community involvement, such as working with local community centers to provide better and more targeted 
services. Several cities experimented with an intensive Community Partnership with Protecting Families, which involved individual family plans and community networks (Daro, Budde, Baker, Nesmith, and Harden, 2005). An early evaluation showed some limitations in the program's implementation and that the rate of families' subsequent involvement with the abuse and neglect system appeared comparable to that of non-involved families (Daro et al., 2005.) Yet, there was a positive impact on caseworkers and families' perception of self (Daro et al., 2005). Community centers that provide parenting support could also offer health care, child care, and more general monitoring. The concept of kinship care builds upon the strength of the child's extended community.

\section{Early Prevention Efforts}

Prevention of abuse and neglect is a critical priority. Family preservation services are "comprehensive, short-term, intensive services for families delivered primarily in the home and designed to prevent the unnecessary out-of-home placement of children or to promote family reunification" (Child Welfare League of America, n.d., para. 1). Though varied, these programs generally provide: family counseling; training in parenting skills; housing assistance; and instruction on financial budgeting, stress management, child development, and health and nutrition issues. These prevention services are offered in the home so workers can observe and help the family in a comfortable environment. According to the Child Welfare League of America, family preservation program evaluations around the country report approximately 80 percent of families who have received family preservation services remain together after one year. In addition, these services appear to improve family functioning and may reduce or delay the number of foster care placements (National Family Preservation Network, n.d.).

Although there are legitimate fears based on the historical misuse of early intervention and the potential for overly zealous intervention with respect to recipients, it is possible to develop programs that are sensitive to culture and that provide support to families rather than further legal involvement. Professor Martha Minow (1994) suggests that local communities work with social scientists to plan culture-specific strategies to meet the families' needs. Increasingly, social workers are recognizing that community-based approaches can improve schools and create jobs, and can also provide better environments to help children flourish (Roberts, 2005).

Home visiting programs have become increasingly popular within the last decade; thousands have been initiated to accomplish a variety of goals (Gomby, Culross, and Behrman, 1999). Most programs provide parents with social support and parenting skills education. Beyond these common characteristics, programs differ in the level and type of services offered and in their specific goals, duration, onset, and intensity of services. Programs may last from several months to several years. 
Finally, turning to substance abuse issues, a major problem for pregnant, drugaddicted women is the lack of treatment facilities. Providing treatment before the child is born would be invaluably helpful for substance abusing women and their families. Children do not need to be removed in order for parents to receive treatment. Child welfare entities and their community-based agencies can provide services such as family and individual therapy, parenting education, and schoolbased services. The State of Illinois provides "recovery coaches" for parents with substance abuse problems who have children in foster care. These coaches help the parents complete treatment, avoid relapse, and negotiate the various treatment and service systems (Allen and Bissell, 2004).

\section{Poverty and Neglect}

Additional preventive services aim to provide sufficient resources so that the family is able to support children. Given the correlation between poverty and involvement in the abuse and neglect system, addressing a family's financial needs is an extremely effective method for deterring child abuse. The provision of adequate housing and other resources might help to reduce the number of neglect and abuse problems. Using homelessness as an example, if lack of a home serves as a basis for denying public welfare benefits to mothers, the family's poverty is only exacerbated. States should be precluded from bringing a neglect petition based on a family's homelessness, ensuring a distinction between actual neglect and poverty.

A comparable problem occurs when TANF forces mothers to work outside of the home and the lack of adequate child care leads to neglect. States are beginning to develop policies to coordinate these two aspects of child welfare-the public aid and the abuse and neglect systems (Andrews, Bess, Jantz, and Russell, 2002). Thus, for example, child welfare caseworkers need access to public welfare resources in order to support the child's family. In 1990, the federal Family Unification Program was created to provide special accommodation to meet the housing needs of children at risk of placement in foster care because of homelessness or other housing problems (Allen and Bissell, 2004). Under the program, a small number of family unification vouchers are made available to families for whom the lack of adequate housing is a primary factor in the separation from their children or in the prevention of reunifying the children with their families (Family unification vouchers, 2003).

\section{Child Abuse and Woman Battering}

There is a strong nexus between adult and child domestic violence; however, there is often disjointed coordination between the domestic violence and child welfare systems (Meier, 2003). Indeed, my domestic violenceclients often felt that reporting the violence against them to public authorities might result in the removal of their children. Where there has been a report of child abuse, in determining whether 
to provide services or remove children, the child welfare worker should evaluate who is doing the battering. If it is the mother's boyfriend or another male in the household, then it may be more appropriate to remove him than the children. Child welfare prevention efforts often require supporting a battered mother so that she can separate from the batterer and provide safety for herself and her children. They also require domestic violence and child abuse training, as well as protocols that are sensitively integrated. For example, a local domestic violence center can provide help to parents of children in the abuse and neglect system.

When their partners batter them, women may be accused of neglect or failing to protect their children from witnessing the abuse. The child protective services agency may threaten the women with removal of their children unless they comply with mandated action, or the children may actually be removed from the household. A landmark decision challenging New York's child protective services system's practices found that the system was disproportionately and inappropriately removing children from the custody of battered women; the women were being blamed for their victimization, and their children were placed in foster care (Meier, 2003; Nicholson, 2002; Ross, 2004b). New York City's Administration for Children's Services claimed that battered women were responsible for engaging in the abuse and for exposing their children to it (Nicholson, 2002). Consequently, they removed the children from their mother's care. None of the plaintiffs had physically abused their child. Most of the children were removed from their mother's care because the mother had either remained with the abuser or had extricated herself from the battering situation but not found a stable environment in which to live. Notwithstanding the mothers' care for their children, the City generally sought to remove the children before removing the batterer (Nicholson, 2002). However, as numerous experts testified at the trial, removing the child is illadvised and a dangerous disruption of the mother-child relationship (Nicholson, 2002; Ross, 2004b).

\section{Post-Removal}

The increasing use of kinship care and encouraging relatives to care for children upon removal allows a child to maintain connections with her family. It also attempts to ensure the safety of her familial placement, keeping the child within a familiar community but in a safer environment. In fact, the ASFA recommends the use of kinship care, and children in kinship care are less likely to receive multiple foster home placements.

The Family-to-Family program in Cleveland allows birth parents and foster parents to work with the child welfare agency to prepare the best long-term plan for the child using both community and familial support (Cahn, 1999). One foster mother involved in this program said she initially believed that she could provide better care for her foster child than could his biological mother, in part due to her greater resources. After watching him interact with his mother, she knew that she 
could never give her foster child what his biological mother could. He was in foster care for four years while the two women worked together.

Longer term foster care is not inherently a bad idea. For older children in particular, foster care may preserve a sense of family and community. If children are placed in one foster family rather than multiple placements, they are able to develop close relationships with both families. Early parental rights termination can be detrimental, in particular for older children who are less likely to be adopted. Parental rights termination also means the rights of other relatives are likewise terminated.

When adoption is clearly warranted, the possibility of adoption with contact, or open adoption, is an option through which the biological parent and child retain some connection and legally enforceable contact. That is, the adoption occurs but the biological parent can still remain in contact with her child. Allowing contact between the birth parents and the adoptee can help birth parents cope with feelings of loss, mourning, and grief without imposing a threat to the adoptive family. Adoption with contact provides legal recognition of the web of relationships forming a child's different families. Open adoption, in the foster care context, can encourage biological parents who are unable to care for a child to voluntarily relinquish their parental rights without completely severing their connection to the child. A number of states have recently enacted legislation designed to validate and enforce such open adoption agreements when both the adoptive and biological parents consent to contact. Other states have passed slightly different statutes authorizing a court to award post-adoption visitation to a child's biological relatives whenever such visitation is in the child's best interest. Almost half of the states currently have legislation allowing enforceable adoption with contact agreements (Child Welfare Information Gateway, 2008). While there are various ethical concerns in negotiating an open adoption, it remains useful to consider this alternative to complete termination of parental rights. However, in other situations, perhaps the parental rights should not be terminated unless there is a strong belief that the child will be adopted; otherwise, the courts may be isolating children from relatives with whom they have close ties.

The Alabama abuse and neglect system provides some ideas for improving the system. As a result of a lawsuit forcing the social services agency to change its practices, a consent decree specifies that the abuse and neglect system's primary goal is to allow children to remain with their families of origin so long as they are safe (R.C. ex. rel. Alabama Disabilities Advocacy Program v. Walley, 2005). The child abuse and neglect agency is required to provide intensive in-home services. This helps keep the children at home. Such services include accompanying a parent to an Alcoholics Anonymous meeting, teaching parents how to help their children do homework, and various forms of counseling. By changing their orientation, the child abuse and neglect workers "learned how to look beyond the often abundant negatives and engage families in a genuine partnership by identifying their strengths" (Cahn, 1999, p. 1221). If children are removed from the home, the new system supports contact between foster children and their families of origin. 
In Alabama, the number of children in foster care declined from 4,625 in 1992 to 3,650 in 1996, and the average time in foster care also decreased (Cahn, 1999).

Other states have developed initiatives that help reunify families when appropriate. In Arizona, a Housing Assistance Program provided support for families where housing was the primary barrier to reunification. As a result, almost 12 percent of the children in foster care between 1991 and 1995 were reunited and the state saved more than $\$ 1$ million in foster care and related expenses (Cahn, 1999, p. 1222). The federal government makes a limited number of housing vouchers available through the Family Unification Program. The vouchers are awarded to families whose lack of housing is a primary risk factor for their children's removal into foster care, or for which lack of housing is the primary risk factor preventing reunification (Allen and Bissell, 2004, p. 61).

Innovative thinking presents possibilities to change the way we think about child abuse and neglect and provides hope for the poor children most likely to be subjected to that system. Creative solutions allow children to remain safely in their families of origin, respecting the parent-child relationship. Ultimately, increased attention to children in their families and communities through early education programs and improved support for parents should decrease the numbers of children in the abuse and neglect system (Eichner, 2005), as will changing the structure of federal financing for abused and neglected children to emphasize family preservation and reunification.

\section{Conclusion}

Within feminism there has been some tension between those who define themselves as protecting children by focusing on children, and those seeking to protect children by placing them in a familial context. This dilemma appears most visibly with respect to whether children should remain in their families of origin. There are advocates for children who believe that children should be removed from mothers with drug or alcohol addictions, regardless of how these women perform as parents. There are advocates for children who believe children should be adopted as quickly as possible and that parental rights should be terminated as soon as possible after a child is removed. This position clearly threatens parents' rights.

Within the feminist community, we have addressed issues concerning women's special connection to children in several ways. When it comes to abortion, we have (in general) firmly supported women's right to choose. In child custody at divorce, we have splintered: some advocate maternal deference, some joint custody, some best interests of the child, and some advocate primary caretaker. For child abuse and neglect, we have focused on battered mothers who abuse or neglect. In adoption, we have begun to focus on the biological mother's interests as well as those of the adoptive mother and the adoptee. This delicate balance-protecting children without subordinating women, or put another way, protecting women without subordinating children-is very difficult. The needs of two outsider groups clearly 
conflict at certain points, as do the issues at the heart of this book, because race, class, sex, and sexuality are critical to define the interests of women and children in this context.

We should not be paralyzed by this conflict. If we refocus to make children safer in the context of their families, both women and children should benefit. Putting the emphasis on children in the context of families and communities helps to change the law and the law's focus on punishing mothers. Along these lines, it is critically important to provide sufficient financial support so that women and their children together can escape abusive situations. Neglect by itself, in the absence of abuse, correlates with poverty. Providing better financial support for women will help in neglectful situations. Our ultimate goal should be to eradicate the situations causing neglect.

With this conflict reframed, we can re-examine the child protective services system. Instead of a focus on respecting the parent-child relationship and preventing abuse and neglect, federal policy towards foster care and adoption seems to have been predicated on stereotypes about foster care, adoption, abused and neglected children, and mothers. It establishes dichotomies: the good mother is capable of reforming herself within one year or else she is a bad parent. Parents and children are adversaries in the abuse and neglect system. Foster care is bad for children so they need to be freed for adoption. These stereotypes have a particularly strong impact on poor children because they are most likely to appear in the child protection system. Outside of cases that involve severe abuse or neglect, family preservation-both pre-removal and post-removal-remains the preferred solution. The origins of the foster care system as an effort to preserve families and allow children to stay in their families of origin reflects the impulse throughout American law that children belong with their parents. The disproportionate use of the abuse and neglect system against racial minorities and the subsequent removal of children for poverty alone indicates the dangers of not presuming family integrity.

The goals of the 1980 legislation-safety and family connection-remain in the child's best interest. Families have strengths that can be supported so that children are not unjustly removed. Rather than providing for only two optionstermination of parental rights and adoption, or reunification —on the misguided assumption that they can be pursued simultaneously, federal law should encourage alternatives such as open adoption or longer term foster care placement. Moreover, the strict time frame wherein states must act on parental rights has a particularly harsh effect on poor children, who are often removed from their homes for neglect stemming from poverty rather than for severe abuse.

Federal law should presume children are best cared for in their families and communities of origin and should include the presumption that these families deserve the support to enable them to act in the child's best interest. Ultimately, individuals, families, and communities are all profoundly affected by the actions of child protective services and the system of adoption. A family-based perspective for all facets of these systems is important (Cahn, 2002). Removing children from 
their homes has implications for the children as individuals and as members of a family; examining family functioning, rather than individual performance, provides the appropriate lens. Thus, offering support to parents helps children; improving education for children helps them as family members. Children and their parents need not be seen as autonomous and potentially conflicting rightsbearers in order to respect the interests of both in their shared relationship, and to protect them from harm. 


\title{
Expanding the Parent-Child-State Triangle in Public Family Law: The Role of Private Providers ${ }^{1}$
}

\author{
Susan Vivian Mangold
}

The parent-child-state constitutional framework was developed in a series of Supreme Court cases that defined when the state could constitutionally intervene in the family. Meyer v. Nebraska (1923), Pierce v. Society of Sisters (1925), Prince v. Massachusetts (1944), and Wisconsin v. Yoder (1972) are landmark cases establishing the parameters of state intervention through a balance of rights and responsibilities among parents, children, and the state (Davis, Scott, Wadlington, and Whitebread, 1997; Mnookin, 1985; Mnookin and Weisberg, 1995). In particular, this chapter challenges that three-party framework as it applies to the dependency system, the social services, and legal system that authorizes and provides for state intervention in the family, based on allegations of child abuse and neglect. ${ }^{2}$ Wilder v. Bernstein (1988) and Smith v. Organization of Foster Families for Equality and Reform (OFFER) (1977) focus on some of the important actors in addition to the parent, child, and state in the dependency system. These "important others," including foster parents and private provider agencies, are discussed in these cases but the parent-child-state doctrinal structure is not explicitly challenged. A review of these cases, along with the history of the dependency system and its current operation, reveal the closed parent-child-state triangle as an incomplete model for the complexity of family law, especially as it applies to abused and neglected children in the dependency system.

The argument for inclusion of private agencies as stakeholders with an important, recognized role in dependency proceedings is ultimately based on the assessment that such inclusion promotes the protection-based best interest of

1 This is an edited version of Mangold's (1999a) article entitled, "Challenging the parent-child-state triangle in public family law: The importance of private providers in the dependency system."

2 This chapter will use the term "dependency system" to describe the whole range of social and legal services provided to children at risk of abuse and neglect at the hands of their caretakers. The term "child protection" will be used in this chapter to describe only the front end of the dependency system-reporting, investigating, and record keeping of allegations of abuse and neglect. 